\title{
David Wilson Reed: The Father of Shiloh National Military Park
}

\author{
TIMOTHY B. SMITH
}

DAVID WILSON REED stood proud and tall as he spoke to the crowd gathered at Shiloh National Military Park on November 22, 1906. The crowd surrounding the monument to his regiment, the 12th Iowa Infantry, heard only clear and unfettered pride as Reed pointed and motioned while describing the 12th Iowa's action in the "Hornet's Nest." The 55-year-old veteran reminded his listeners how the regiment and its brigade had "held the Confederates at bay all day long" on April 6, 1862; even 62 Confederate guns had "failed to move the Union forces from their position."

Reed's pride was understandable. He had been a soldier whose most notable experience in the Civil War was being wounded at Shiloh. He was a historian whose work concentrated almost exclusively on that battle. He was an extremely particular man who always strove for truth and accuracy, as his writings on Shiloh show. The monument dedication on November 22, 1906, was, therefore, a fitting culmination of Reed's entire private and professional life.

Reed and the monument, and Shiloh National Military Park itself, were also parts of a larger phenomenon. The decade of the 1890 s was a period of memorialization and remembrance

1. Alonzo Abernathy, Dedication of Monuments Erected by the State of Iowa (Des Moines, 1908), 226-27.

THE ANNALS OF IOWA 62 (Summer 2003). (C) The State Historical Society of Iowa, 2003. 


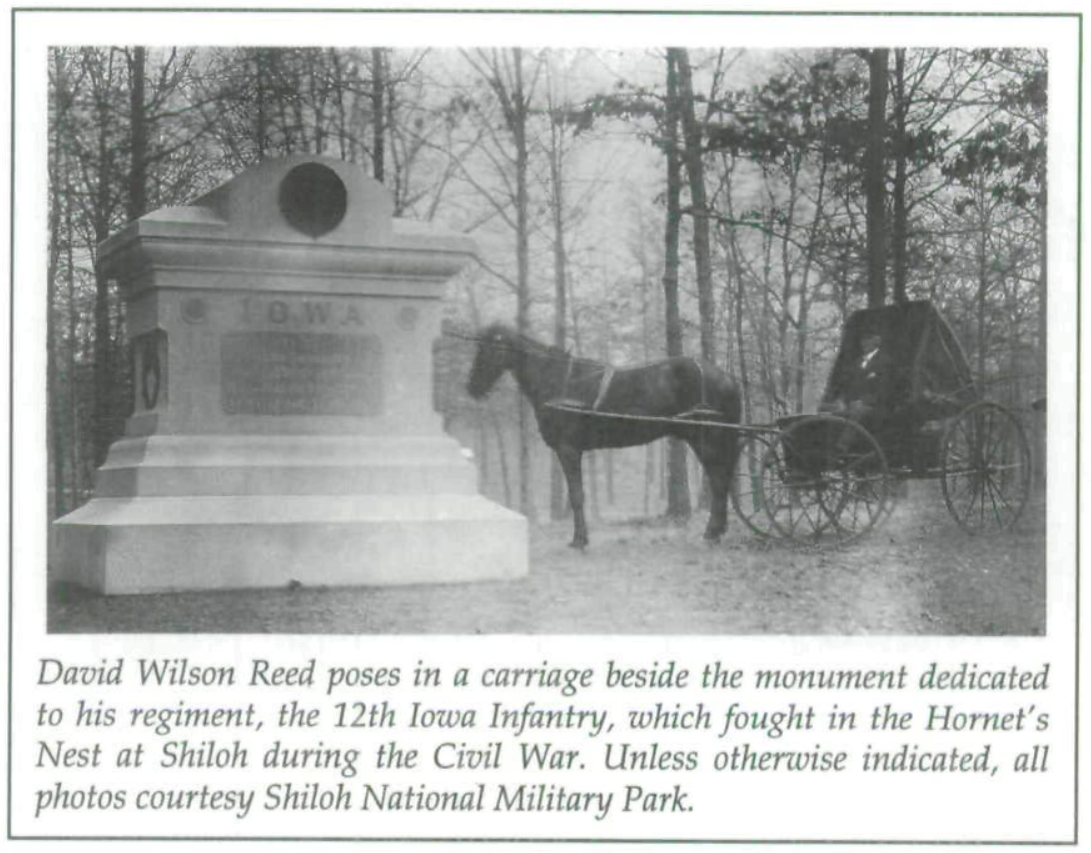

that emphasized the honor, courage, and bravery of Civil War soldiers. During a time of national healing after many years of war and violent reconstruction, the North and South seemingly set aside the racial issues that had divided them for so long and focused instead on issues they could agree on. Memorialization of the war changed the face of the American landscape as monuments went up all over the nation, veterans' reunions became commonplace, and Congress established five national military parks. Those parks provided Americans with tangible links to their common heritage of courage, bravery, and honor. ${ }^{2}$

2. Civil War memory has become a popular subject among historians. In one of the most recent and best studies, David Blight, Race and Reunion: The Civil War in American Memory (Cambridge, MA, 2001), investigates the role of race in producing a national memory of the war. Edward T. Linenthal, in Sacred Ground: Americans and Their Battlefields (Urbana, IL, 1991), looks at the American preoccupation with its fields of conflict. Similarly, Carol Reardon, in Pickett's Charge in History and Memory (Chapel Hill, NC, 2003), examines how the memory of that event at Gettysburg affected how Americans viewed their history. Gaines M. Foster, in Ghosts of the Confederacy: Defeat, The Lost Cause, and the Emergence of the New South (New York, 1987), explores the southern perspective on the war and how that section interpreted the conflict and its re- 
David W. Reed's part in the conservation of the collective memory of the Civil War offers the opportunity for a case study of battlefield preservation. As the foremost authority on the battle, Reed acted as the most authoritative figure in establishing the battlefield. More than any other single individual, he affected the placement of markers and monuments, guided construction in the park, dominated the interpretation of the battle, and shaped the battlefield into what it is today. Thus, Reed stands as "the Father of Shiloh National Military Park." ${ }^{3}$

Understanding Reed's role at Shiloh is important for several reasons. First, it can be used to document similarities and differences in other military parks, such as Antietam, ChickamaugaChattanooga, Gettysburg, and Vicksburg, which were all created during the same decade. Second, an examination of his role at Shiloh provides insight into the mindset of park founders, allowing modern park visitors to better understand what they are seeing. Third, and most important, Reed and his contemporaries formed the basis of a battlefield preservation movement that continues to this day. The parks built by Reed and his associates in the 1890s established the pattern for later generations of Civil War parks. Realizing what drove the original park founders can help us today to remember why they exist and why Americans continue to flock to them by the millions.

DAVID WILSON REED was born on April 2, 1841, in Cortland, New York, of New England pioneer stock (his paternal grandparents had been born in Putney, Vermont, during the American Revolution). In 1855, John and Hannah Reed and

sults. G. Kurt Piehler, Remembering War the American Way (Washington, DC, 1995), takes a more general view, researching and analyzing the overall process of remembering America's wars. See also Mary Munsell Abroe, "'All the Profound Scenes': Federal Preservation of Civil War Battlefields, 1861-1990" (Ph.D. diss., Loyola University, 1996); Terrence J. Winschel, "Stephen D. Lee and the Making of an American Shrine," Journal of Mississippi History 63 (2001), 17-32; and Timothy B. Smith, This Great Battlefield of Shiloh: History, Memory, and the Establishment of a Civil War National Military Park (Knoxville, TN, 2004).

3. Reed's successor as head of the park, DeLong Rice, acknowledged to Reed that "the entire activities of the Commission emanated from you during your active service here." DeLong Rice to D. W. Reed, 4/23/1914, series 3, box 2, folder 141, Shiloh National Military Park Archives (hereafter cited as SNMP). 
their three children-Jennie, Milton, and David-moved from New York to Elon in Allamakee County, Iowa, where the elder Reed and his boys farmed. ${ }^{4}$

The Reed farm must have been at least moderately successful because at a time when higher education was not the norm, young David Reed managed to enroll at Upper Iowa University in nearby Fayette in 1860. The Civil War disrupted Reed's studies, however. In response to calls for volunteers, Reed and his friends at Upper Iowa joined together to form an infantry company they called the University Recruits and enlisted in the Union army on September 15, 1861. Joining that company would change Reed's life forever. ${ }^{5}$

At five feet seven inches tall with hazel eyes and brown hair, the 20-year-old Reed mustered into the army and became part of Company C, 12th Iowa Infantry. He met many new friends and formed lasting relationships with others he had known only casually at Upper Iowa. His friend William W. Warner became captain of the new company, while Reed and another friend, David B. Henderson, formed a lifelong closeness that would shape the rest of Reed's life. The regiment trained at Camp Union in Dubuque, then transferred to Benton Barracks near St. Louis, where Reed contracted the mumps. Soon, the regiment received new Enfield rifles, which the men carried proudly as they headed south to confront the enemy. Their first campaign ended with the capture of Fort Henry in February 1862 , but the regiment first became engaged in actual fighting later that month at Fort Donelson. ${ }^{6}$

The Army of the Tennessee's springtime move south along the Tennessee River brought Reed and the 12th Iowa to Pittsburg Landing, where the regiment camped for several weeks on a

4. See descriptions on photographs in series 3, box 5, folders 253 and 255, SNMP.

5. David W. Reed, Campaigns and Battles of the Twelfth Regiment Iowa Veteran Volunteer Infantry: From Organization, September, 1861, to Muster-Out, January 20, 1866 (n.p., n.d.), 250.

6. D. W. Reed Compiled Service Record, National Archives and Records Administration, Washington, DC (hereafter cited as NARA); Reed, Campaigns and Battles of the Twelfth Regiment, 11; Charles B. Clark and Roger B. Bowen, University Recruits-Company C: 12th Iowa Infantry Regiment, U.S.A., 1861-1866 (Elverson, PA, 1991), 38. 
high hill with easy access to a flowing creek just below. A part of James M. Tuttle's brigade in W. H. L. Wallace's division, Reed and the 12th Iowa were destined to see some of the most famous fighting at Shiloh. During the unexpected Confederate attack on the morning of April 6, 1862, Reed's regiment formed on the color line and moved forward with the brigade. Marching on the Eastern Corinth Road, their column met advancing Confederates at about 8:30 a.m. and immediately went into position along an old farm road, later termed the "Sunken Road." One of the units in the famous "Hornet's Nest," Reed's regiment repelled seven or eight different attacks, sometimes counterattacking and driving the southerners away. All day long, the Union line held firm against repeated attack, but crumbling flanks doomed the position. The regiment tried to retreat but found Confederates on each flank and in front. The Iowans tried to fight their way out, but soon realized that further combat would be suicidal. ${ }^{\text {? }}$

As the regiment prepared to surrender, a Confederate bullet slammed into Reed's thigh. Unable to surrender formally himself, Reed watched his comrades do so. He remained on the field during the long, miserable, rainy night of April 6. A Union counterattack the next day drove away the Confederates, who left Reed behind as they retreated. "Recaptured," as he said, by advancing Union soldiers, Reed received care for his wound and was sent north to a hospital in Mound City, Illinois. ${ }^{8}$

Reed's wound was not life threatening, and fortunately he did not lose his leg. By August, he had recovered and rejoined his command in time for the October battle at Corinth, Mississippi, where he served in the famous "Union Brigade" made up of remnants of regiments that had surrendered at Shiloh. He continued to serve in the Army of the Tennessee during the Vicksburg, Meridian, and Missouri campaigns, the battles of Tupelo and Nashville, and finally the Mobile Campaign. Marching and fighting all across the South, Reed and his regiment saw places he had never before imagined. At one point in New Orleans, the regiment camped on the War of 1812 Chalmette battlefield. Reed wrote home in wonder over the monument to

7. Reed, Campaigns and Battles of the Twelfth Regiment, 42-61.

8. Ibid., 250. 


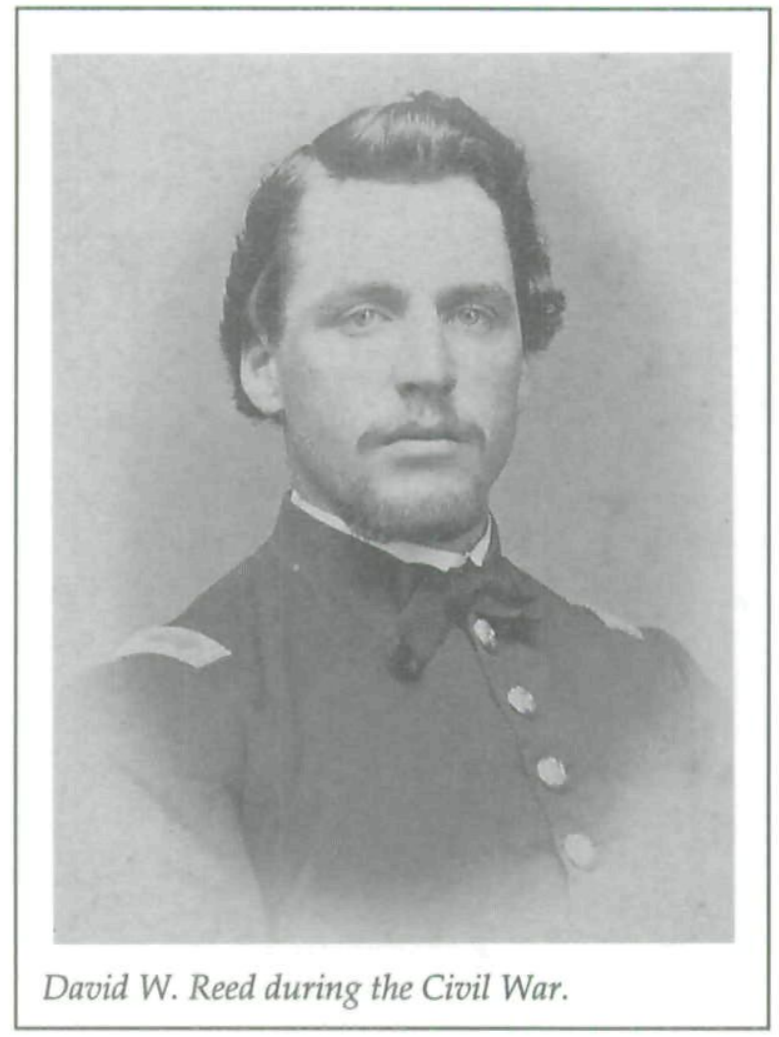

Andrew Jackson, perhaps developing the passion he would later feel while commemorating another famous battlefield. ${ }^{9}$

Throughout the war, Reed steadily rose in rank and duty. He became second and then first lieutenant in his company, and commanded the unit on several occasions when the captain was absent. His superiors also frequently detailed him for odd jobs, such as inspector. In early 1865, Reed became a captain, commander of Company $\mathrm{C}^{10}$

Reed always acted with a military bearing, and he expected similar behavior of his men. He once fined a subordinate five dollars (when monthly pay was \$13) for not having the proper

9. D. W. Reed to "Ella," 2/25/1865, series 3, box 1, folder 17, SNMP. For a detailed account of these operations, see Reed, Campaigns and Battles of the Twelfth Regiment.

10. D. W. Reed Compiled Service Record. 
military buttons. Surprisingly, the offender did not complain and simply wrote to Reed asking for a receipt for his payment. Reed could also be caring, however. For example, he accompanied the body of his friend, Captain William W. Warner, home to Iowa after his death in 1863 . He gained the affection of Warner's family for the act; they presented him with the captain's personal copy of Scott's Military Dictionary. Unfortunately, Reed remained in Iowa too long and was court-martialed. The court found him guilty but inexplicably assigned no punishment. ${ }^{11}$

Reed's conduct on the battlefield was courageous. His horse was shot from under him at Tupelo. In official reports, his commanders commended him for gallantry, and he received a brevet major's rank for gallantry at Spanish Fort near Mobile in April 1865. By the end of the war, Reed held separate commands, one at Center and one at Blue Mountain, Alabama. The regiment soon mustered out, however, receiving final pay on January 25, $1866 .^{12}$

REED RETURNED HOME to Waukon, Iowa, to begin his life anew. He returned to his education, studied law, and was admitted to the Iowa bar in June 1867. He also got involved in politics; he ran for and won the position of county recorder for Allamakee County, a position he held for ten years. He was also a member of the local school board and the Methodist church. ${ }^{13}$

In his private life, Reed continued his courtship of Ellen E. Manson that he had begun during the war. During the last year of Reed's service, his increasing correspondence betrayed his affection for the seemingly unconvinced "Ella" and his impatience with her inattention to him. Reed sent poems and glowing letters

11. Ibid.; A. C. Clark to D. W. Reed, 12/6/1865, series 3, box 1, folder 51, SNMP.

12. U.S. Government, War of the Rebellion: A Compilation of the Official Records of the Union and Confederate Armies, 128 vols. (Washington, DC, 1880-1891), ser. 1, vol. 24, part 2: 624 and ser. 1, vol. 45, part 1: 463; D. W. Reed Compiled Service Record; Reed, Campaigns and Battles of the Twelfth Regiment, 243, 250.

13. "David Wilson Reed," in Memorials of Deceased Companions of the Commandery of the State of Illinois, Military Order of the Loyal Legion of the United States (Wilmington, NC, 1993), 252-53; Certificate of Reed's Admission to Iowa Bar, 6/17/1867, series 3, artifact cabinet 7, drawer 1, folder 286, SNMP; Reed, Campaigns and Battles of the Twelfth Regiment, 251. 
remembering important events in their courtship. In other letters he imagined their future. His impatience was always at the forefront, however. At one point he complained that he had waited for a letter "until my patience is nearly worn out." $\mathrm{He}$ was also haunted by jealousy. One particular nuisance was a rival, "long John," whom he also referred to as the "Gay and Festive John." Reed reminded Ella, "your 'bow is in the army." " Eventually, Reed's persistence paid off, and he won Ella from the irritating John. They married on September 20, 1866, and eventually had three children who lived to adulthood: Minnie Althea, Milton, and Gertrude. ${ }^{14}$

David and Ellen Reed named Milton after David's brother, a private in Company A, 27th Iowa Infantry, who had died of disease in Jackson, Tennessee, on February 2, 1863. David compulsively searched for the location of his brother's burial site. Buried originally in Jackson, Milton's body was later moved to the National Cemetery in Corinth, Mississippi, when the War Department established that cemetery after the war. David corresponded with E. B. Whitman, who, ironically, was at that time working to build another national cemetery-the one at Pittsburg Landing. David learned that Milton's grave was unmarked, but eventually, after several years, he was able to decipher the numbering system at the cemetery and locate the grave. David then turned his attention to getting a new stone for his brother. That got much easier when he became associated with nearby Shiloh and began making trips to the area. David's efforts to mark Milton's grave demonstrated his devotion to his family as well as his obsession with accuracy, which would become his trademark in his historical profession. ${ }^{15}$

Through the years after the Civil War, Reed held numerous government posts, including commissions in 1867 as a notary public and deputy collector for the Internal Revenue Service for Iowa's Third District, and in 1890 as supervisor of the census for

14. D. W. Reed to Ellen Manson, 11/19/1864, 12/23/1864, 1/28/1865, $2 / 18 / 1865,4 / 22 / 1865$, and 4/29/1865, series 3 , box 1 , folders $10,18,20,24$, and 27, SNMP; and Poem, ibid., folder 44; "David Wilson Reed," 253; Reed, Campaigns and Battles of the Twelfth Regiment, 251.

15. Quartermaster General's Office to D. W. Reed, 5/6/1895, series 3, box 1 , folder 93, SNMP; and E. B. Whitman to D. W. Reed, 2/4/1867, ibid., folder 57. 
Iowa's Second District. In 1878 he became captain of Company E, 9th Iowa National Guard Regiment. Later he held other notable positions, such as assistant inspector in the Iowa Department of the Grand Army of the Republic and aide-de-camp in the national Grand Army of the Republic. ${ }^{16}$

Through the years, Reed kept in contact with his old comrades. One friend who had an enormous impact on Reed's life was David B. Henderson, also of Company C, 12th Iowa. Henderson worked for the Internal Revenue Service and helped Reed get the deputy collector position. As Henderson rose in status, he always kept his friend in mind. Reed also began to gain more status on his own. Recognizing the importance of his military service, he wrote to the War Department in 1881, requesting that several feats be added to his military record. ${ }^{17}$

Reed's reputation had grown to the point that by 1880 , he had enough influential friends to secure an appointment from President Rutherford B. Hayes as postmaster of Waukon, Iowa. The president acted on recommendations by Reed's powerful friends, one of whom was Henderson, who was elected to Congress in 1882. Reed held the postmaster's position until 1887. By 1891, he and his family had moved to Evanston, Illinois, near Chicago, where he entered the real estate business. ${ }^{18}$

In addition to holding government jobs, Reed was also becoming a historian. He was a member of several veterans' associations, and was active in both the 12th Iowa and "Iowa Hornet's Nest Brigade" veterans' reunions. Both elected him as their historian. The survivors of the 12th Iowa elected him at their first meeting in 1880 and charged him to write a history of the regiment. At the 1894 meeting, he reported that the book was written and turned it over to committee for publication. ${ }^{19}$

16. Various D. W. Reed documents and commissions, all in series 3, artifact cabinet 7, drawer 1, folders 282-87, SNMP; Reed, Campaigns and Battles of the Twelfth Regiment, 250-51.

17. D. B. Henderson to D. W. Reed, 4/29/1868, series 3, box 1, folder 83, SNMP; and W. L. Alexander to D. W. Reed, 12/23/1881, ibid., folder 84 .

18. D. W. Reed Appointment, 12/21/1880, series 3, box 1, folder 79, SNMP; and copy of 1867 letter on real estate letterhead, ibid., folder 82; Reed, Campaigns and Battles of the Twelfth Regiment, 251.

19. First Reunion of Iowa Hornet's Nest Brigade, series 3, box 4, folder 216, SNMP; Reed, Campaigns and Battles of the Twelfth Regiment, 1. 


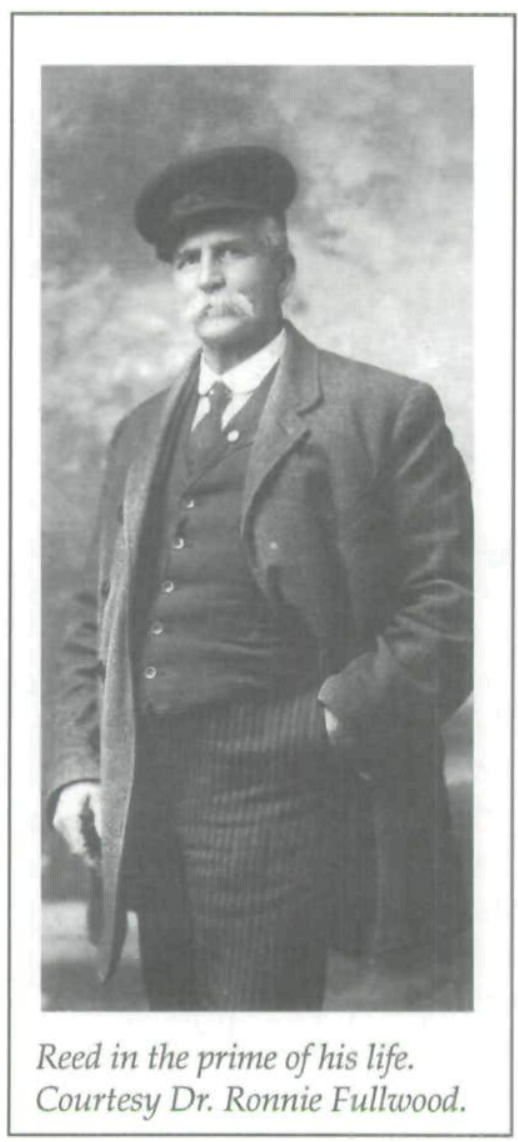

BY 1895, many factors had combined to prepare Reed for his role as the father of Shiloh: he had experience as a government worker; he knew influential people in powerful positions; he had experience as a historian; and he had a compelling interest in and link to the Battle of Shiloh. More than 30 years after the battle, Shiloh remained important to him.

At the same time, the U.S. Congress was in a mood to preserve Civil War battlefields: it had established Chickamauga and Chattanooga National Military Park and Antietam National Battlefield in 1890, Gettysburg National Military Park in 1895, and Vicksburg National Military Park in 1899. As part of the memorialization efforts of the 1890s, Congress established Shiloh National Military Park in December 1894. Reed's old friend David Henderson, now in Congress and soon to be Speaker of the House, authored the legislation that created the park. The congressman had, of course, fought at the battle, and his brother Thomas had been killed there and now rested in Shiloh National Cemetery at Pittsburg Landing. Henderson wanted his friend to supervise the historical work at Shiloh, so he asked Reed to provide a record of his service for use in the "fight for the Secretaryship of the Shiloh Commission." Thanks to Henderson's influence, on March 26, 1895, Secretary of War Daniel S. Lamont appointed Reed as the park's secretary and historian. ${ }^{20}$

20. D. B. Henderson to D. W. Reed, 1/13/1895, series 3, box 1, folder 90, SNMP; D. W. Reed appointment, 3/26/1895, RG 92, E 713, NARA. 
Henderson used his influence to get other friends appointed as well. The chairman of the Shiloh commission was Army of the Tennessee representative Colonel Cornelius Cadle, formerly of the 11th Iowa and a friend of Henderson. T. J. Lewis and F. A. Large were also 12th Iowa veterans who ultimately received positions on the park workforce. The secretary of war appointed Major General Don Carlos Buell to represent the Army of the Ohio and Colonel Robert F. Looney to represent the Confederates. Chickamauga battlefield road engineer Atwell Thompson became chief engineer, with Reed as secretary and historian. ${ }^{21}$

The commission soon went to work, each department going about its own business. Thompson and local lawyers worked to clear land titles and then to buy the tracts. Chairman Cadle, who maintained his office in Cincinnati, kept one eye on the park and one on Washington. Reed remained in Evanston, Illinois, working over his copy of the battle reports and correspondence in an attempt to position lines of battle accurately. He made frequent trips to the battlefield for meetings, veterans' reunions, and visits by high-ranking luminaries. When they visited, Reed and the commissioners lived in tents situated in the national cemetery. ${ }^{22}$

Large veteran turnouts at reunions provided Reed with oral evidence he needed to clarify any confusion about the battle in the Official Records' reports and letters. Emotional veterans who returned on the anniversary of the battle often found their old positions and reminisced about their actions. Most of those veterans were, of course, of lower rank, so they could describe only a small portion of the battle as they had seen it from their limited viewpoints, but their remembrances were invaluable to Reed in his work. Higher-ranking officers were particularly helpful to Reed in locating positions and clearing up misunderstandings. When generals could not travel to Shiloh, Reed went to them. He visited John A. McClernand in Illinois and A. P. Stewart and James R. Chalmers in Chattanooga. At other times, senior officers of both armies returned to the battlefield. Often,

21. D. B. Henderson to D. W. Reed, 3/28/1895, series 3, box 1, folder 91 , SNMP; David W. Reed, The Battle of Shiloh and the Organizations Engaged (Washington, DC, 1902), 6.

22. D. W. Reed Business Cards, series 3, box 1, folder 86, SNMP. 
the return of these well-known men aroused excitement in the area. On one occasion, a crowd of veterans wanted to hear a speech from Confederate General A. P. Stewart, but he could not be found because he was "off locating places in the battle." Commission member Buell, of course, was especially active in locating troop positions. ${ }^{23}$

Reed accompanied many of the veterans to the field and then verified their stories in the Official Records. He also spent countless days wandering the battlefield alone, looking for signs of action and militarily advantageous positions. He found much physical evidence, such as tent rings and sinkholes. In Cloud Field, remnants of mud ovens used by Stephen A. Hurlbut's division still dotted the countryside. Somberly, too, he noted that physical evidence of regimental burial grounds remained. ${ }^{24}$

Once Reed located the primary troop positions, he began the process of marking the field. That in itself was a major task, requiring the cooperation of many people. Taking its cue from other battlefield parks, which Reed visited, the commission determined that tablets would "mark, in letters of iron, the history of the battle." Cannon would locate artillery positions. State monuments would add to the scene. ${ }^{25}$

Realizing that this process would take years, Reed, in the spring of 1896, placed some one hundred temporary wooden signs at prominent points on the field to offer some interpretation while the park was being developed. Painted white with red letters, these poplar boards primarily located prominent natural features such as fields, springs, and houses. In several instances, however, Reed marked the locations of the most hotly contested battle sites such as the Bloody Pond, the Peach Or-

23. D. W. Reed to Cornelius Cadle, $1 / 30 / 1897$, series 1 , box 38 , folder 623 , SNMP; D. W. Reed to Cornelius Cadle, 6/1/1897, ibid., folder 624; Shiloh National Military Park Commission Daily Events, 5/20/1901 and 6/4/1901, SNMP, pp. 29, 31; "Federal Veterans at Shiloh," Confederate Veteran 3 (April 1895), 104. Similar visits by fellow park commissioners from Gettysburg and Chickamauga also helped Reed plan construction and interpretation.

24. Cornelius Cadle to George W. Davis, 9/30/1896, RG 92, E 712, box 1, NARA. 25. Cornelius Cadle to Secretary of War, 2/23/1901, in Shiloh National Military Park Commission Daily Events, 2/20/1901, SNMP, p. 23; Cornelius Cadle to Robert F. Looney, 8/10/1895, Robert F. Looney Collection, Memphis/Shelby County Public Library, Memphis, TN. 
chard, the Sunken Road, and the Johnston oak tree. Reed and Cadle wanted the boards to go up "before the spring excursion parties begin to arrive" so that locations were identified for visitors and they had something to look at until the monuments and markers could be completed. ${ }^{26}$

The commission tackled the massive task of obtaining and erecting tablets in an orderly fashion. Reed concentrated first on placing tablets to mark campsites. By November 1900, Chief Engineer Thompson had placed all 83 on the field. A number of permanent road signs also went up during that time. Reed then turned to the more complicated process of erecting position tablets. To mark the first day's action, Reed needed 199 square tablets with ornamental corners. Those arrived from a Chattanooga foundry in May 1901, and Thompson immediately placed them on the field. Over the next two years, the second day's tablets, as well as division, corps, and army tablets, as well as those displaying the regulations governing the park, were also placed on the field. By 1908, the commission was able to report that Reed's work of erecting tablets on the battlefield had been completed. There were 651 tablets: 226 Union, 171 Confederate, and 254 road signs and explanatory markers. The cost of these tablets totaled $\$ 11,726.14$.

Reed dominated the decisions on the design and placement of the tablets. He was the one who decided on colors, inscriptions, and positions; he also made the foundry correct several errors. Once the tablets arrived at Pittsburg Landing and Thompson's crews erected them according to Reed's notes, he returned frequently to inspect them. He found tablets facing in the wrong direction and ordered the laborers to point them the appropriate

26. Atwell Thompson to Cornelius Cadle, 1/27/1896, series 1, box 37, folder 620, SNMP; D. W. Reed to Cornelius Cadle, 3/4/1896, ibid., folder 621; Atwell Thompson to Shiloh National Military Park Commission, 7/10/1896, series 1, box 40 , folder 640 , SNMP.

27. Atwell Thompson to D. W. Reed, 6/11/1901, series 1, box 25, folder 369, SNMP; Annual Report of the Secretary of War, 1900, 213; ibid., 1901, 384; ibid., 1902, 23; ibid., 1903, 236; ibid., 1904, 267; ibid., 1905, 150; ibid., 1906, 318; ibid., 1908, 178; Shiloh National Military Park Commission Daily Events, 2/10/1902, pp. 85,113 . According to the Inflation Calculator based on data from Historical Statistics of the United States (Washington, DC, 1975) at www.westegg.com/ inflation, the cost of the tablets is equivalent to $\$ 243,385$ in 2002 dollars. 
way. He worded the text so that a visitor could "follow easily the movements of each organization from the morning of April 6, 1862 , to the close of the battle." Each tablet pointed the visitor to the unit's next location marked by a plaque. Thus, Reed established the first permanent interpretive scheme at the park. ${ }^{28}$

At the same time as the commission was erecting tablets, it was also placing artillery pieces on the field. Cadle had ordered 215 cannon tubes from the War Department in November 1896. The secretary of war, with many obsolete pieces of ordnance filling arsenals, had already turned over hundreds of pieces to other parks. Now, he approved the guns for Shiloh, and Cadle worked out the details of the shipment. In all, the park received some 250 cannon tubes from five different arsenals. ${ }^{29}$

Reed and the commission were not yet ready to place the cannon, however. The guns needed carriages, and bids would have to be let for their construction. In the meantime, Cadle and Reed opted for "a platform of crib work" to house the guns. The carriages on which the guns would sit did not arrive at Shiloh until July 1901. After several months of wrangling with the foundry over parts that did not fit, the government exercised an option to buy more carriages, eventually a total of $250 .^{30}$

As Thompson's men placed the guns, they had many questions. Thompson asked Reed for an accurate description of a battery's correct deployment. Reed told him to place the guns in

28. J. E. Evans to Cornelius Cadle, 9/9/1902, series 1, box 25, folder 370, SNMP; Shiloh National Military Park Commission Daily Events, 11/23/1900, 1/9/1901, and 10/23/1901, SNMP, pp. 9, 16, 39; Shiloh National Military Park Commission Annual Report, 10/31/1899, series 1, box 40, folder 641, SNMP. Reed made the foundry correct the misspelling of Prentiss's name as "Prentice" on the 61st Illinois monument.

29. J. W. Irwin to J. M. Riddell, 3/5/1897, series 1, box 25, folder 361, SNMP; Cornelius Cadle to Secretary of War, 11/14/1896, RG 92, E 713, NARA; "List of Cannon to be turned over to the Shiloh Battlefield Commission," undated, series 1 , box 24, folder 359, SNMP.

30. George W. Davis to Cornelius Cadle, 3/13/1897, series 1, box 25, folder 361, SNMP; Atwell Thompson to Cornelius Cadle, 12/8/1898, series 1, box 40, folder 641, SNMP; Cornelius Cadle to Ross-Meehan Foundry Company, 12/12/1901, series 1, box 25, folder 361, SNMP; Shiloh National Military Park Commission Daily Events, 7/13/1901, 8/10/1901, 1/2/1902, 1/5/1902, $1 / 17 / 1902,1 / 18 / 1902,1 / 28 / 1902,2 / 10 / 1902,3 / 22 / 1902,11 / 17 / 1902$, $12 / 27 / 1902,1 / 13 / 1903,1 / 31 / 1903,5 / 1 / 1903,8 / 1 / 1903$, and $9 / 18 / 1903$, SNMP, pp. 34-35, 59-60, 150, 161, 163, 164, 172, 176, 178. 


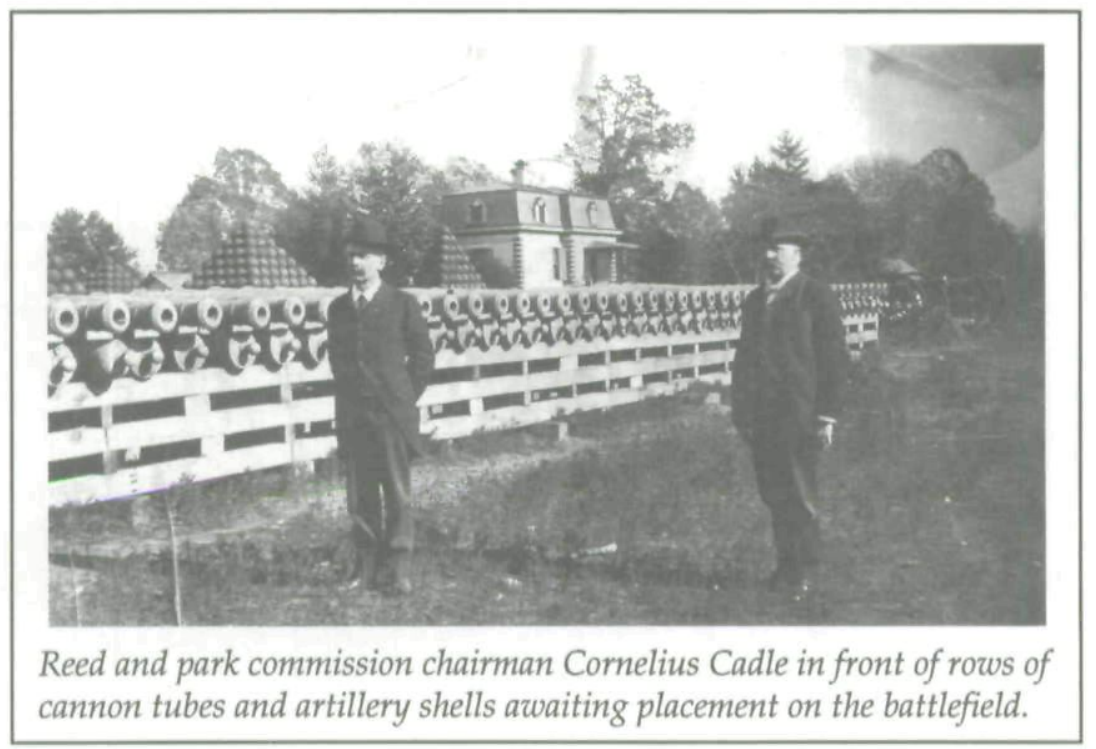

a battery covering 100 feet, with the guns 16 feet apart. They were to be placed in front of the tablet marking the unit's position, with the butt of the guns in line with the tablet post. With those instructions, Thompson soon placed each gun on the field, bolting them down firmly to concrete bases for support and security. Thompson and his crews finished placing all of the guns on September 17, 1903. ${ }^{31}$

The placement of tablets and artillery pieces was only half of the monumentation effort at Shiloh. More impressive than even the hundreds of cast iron tablets were the stone monuments that soon covered the 3,500-acre field. Numbering 156 in all, these monuments of varying types of stone not only marked additional troop positions, but they also grandly honored the units. This flurry of monument placement at Shiloh corresponded with the general trend of 1890s-era nationalism and

31. D. W. Reed to Atwell Thompson, 7/19/1901, series 1, box 25, folder 361, SNMP; Cornelius Cadle to Ross-Meehan Foundry Company, 12/12/1901, series 1, box 25, folder 361, SNMP; Shiloh National Military Park Commission Daily Events, 7/13/1901, 8/10/1901, 1/2/1902, 1/5/1902, 1/17/1902, $1 / 18 / 1902$, 1/28/1902, 2/10/1902, 3/22/1902, 11/17/1902, 12/27/1902, 1/13/1903, 1/31/1903, 5/1/1903, 8/1/1903, and 9/18/1903, SNMP, pp. 34-35, $59-60,150,161,163,164,172,176,178$. 
monumentation, portrayed not only on battlefields but also on courthouse lawns and prominent avenues all across the nation.

The park's 1894 enabling legislation authorized "any State that had troops engaged in the battle of Shiloh to enter upon the lands of the Shiloh National Military Park for the purpose of ascertaining and marking the lines of battle of its troops engaged there." Many states responded enthusiastically. In the early 1900s, state after state began appointing battlefield commissions to locate troop positions and erect monuments. Iowa placed 12 monuments. The enabling legislation allowed states to place monuments of any size and shape at any location, but only with the approval of the secretary of war, who acted on the approval of the commission, which in turn acted on the approval of David W. Reed. ${ }^{32}$

ALTHOUGH REED was the recognized authority on Shiloh, his historical interpretation of the battle and his marking of troop positions were not without controversy. Inflamed passions of elderly men and their fading memories combined to produce disagreements over when, where, and how certain events happened. Reed's obsession with accuracy and his sometimes combative personality exacerbated the controversy when someone challenged his conclusions. A few veterans questioned Reed's marking of the battlefield, but most of the controversy resulted from interpretation of the historical record. Issues such as the role of the Army of the Tennessee compared to that of the Army of the Ohio, the Confederates' surprise attack on the first day of the battle, and Lew Wallace's march caused heated confrontation. Some disputes, such as wrangling over the position of the 81st Ohio monument and the inscriptions on the 15th and 16th Iowa monuments went all the way to the secretary of war for resolution. One veteran remembered, "Major Reed could scrap for years." In most cases, Reed's thorough research and knowledge of the battle prevailed. He was able to silence most critics, thus producing what he considered an accurate portrayal (his main goal) of what had happened at Shiloh. The memory of Shiloh

32. Congressional Record, 53rd Cong., 3rd sess., 27, 1:19-20. 
was larger than Reed or the commission, but Reed exerted amazing influence and wanted that history to be accurate as he saw it. ${ }^{33}$

Despite the controversies, Reed's marking of the battlefield and his subsequent writings created the dominant historical interpretation of the battle of Shiloh. Reed instituted a set pattern of interpretation at Shiloh, most of which centered on the importance of the Hornet's Nest and Sunken Road, the position his regiment had held. In 1896 Reed had placed the temporary wooden signs at prominent places on the field, such as the Bloody Pond, the Peach Orchard, the Sunken Road, and the Johnston oak tree. These easily accessible battle sites, so marked, quickly became accepted as the dominant attractions on the battlefield, and thus became the center of Shiloh interpretation even after the field was marked with monuments and tablets that actually told a different story. ${ }^{34}$

For example, Reed marked the Bloody Pond, which today is one of the most popular sites in the park. No after-action report mentioned the pond, and the account of blood-stained water came only from a local resident walking the field after the battle. In addition, other people reported similar instances of bloodstained water at other locations. But Reed marked this pond, and it has become known to history as Bloody Pond..$^{35}$

Similarly, Reed seems to have overstated the effect and organization of Ruggles's Battery, which took on larger-than-life status for Reed. He asserted that the Confederates had to assemble a massive line of artillery to break the Hornet's Nest line, and then only succeeded in driving away the supporting Union artillery. Yet few Union or Confederate reports even mentioned the barrage of 62 cannon. The best recent research has concluded that, due to attrition, the Confederates were only able to gather about 53 cannon at the site, and those did not fire in concert, the impression the visitor gains at the park. Likewise, the Johnston oak tree, located by Senator Isham G. Harris, had

33. John Hayes to Walter I. Smith, 1/6/1906, RG 92, E 712, box 3, NARA. For an in-depth discussion of the controversies at Shiloh, see Smith, This Great Battlefield of Shiloh, 81-88.

34. Atwell Thompson to Cornelius Cadle, $1 / 27 / 1896$, series 1, box 37, folder 620, SNMP; D. W. Reed to Cornelius Cadle, 3/4/1896, ibid., folder 621.

35. "The Bloody Pond," Shiloh-Bloody Pond-Vertical files, SNMP. 
little to do with Confederate commander Albert Sidney Johnston's death. Nonetheless, it became known as the tree under which Johnston allegedly fell because Reed nailed the board that said as much to the tree. ${ }^{36}$

Most importantly, the Sunken Road seems to have been an embellishment of Reed's rather than a real battle location. Although no federal report of the battle mentions a "sunken road," and only a few postwar accounts even referred to the old road, during the 30 years between the war's end and the founding of the park, Reed had become convinced of the importance of the Sunken Road. Reed's 12th Iowa had defended the area, which no doubt played heavily in his mind when he emphasized the importance of the position. Reed also served as the historian for a veterans' organization called the "Hornet's Nest Brigade" that came into being with its first reunion at Des Moines in 1887. In addition, Benjamin Prentiss, who surrendered in the Hornet's Nest, had made dramatic claims in his battle report that he had saved the day for the Union. Of course, battle veterans tend to view the operations they are involved in as more important than events that happened elsewhere. But in this case, one veteran's perceptions shaped the larger understanding of the battlefield and its history. The result of Reed's conviction that the Hornet's Nest was the pivotal action at Shiloh is seen in the monumentation and historical writing on the battle. Reed's writings subtly argue that the Hornet's Nest was the key site in the battle. Veterans took this cue and placed three state monuments in the area, more than any other grouping on the battlefield. ${ }^{37}$

WHILE REED was the dominant force in locating troop positions and marking them on the field, he was also involved in other important historical work. He used the expertise gained in his studies of the battle to produce two documents that still stand as basic sources for understanding the Battle of Shiloh: the Reed maps of the battle and the official commission history.

36. Stacy D. Allen, "Shiloh!: The Campaign and First Day's Battle," Blue and Gray 14 (1997), 53.

37. Reed, The Battle of Shiloh and the Organizations Engaged, 7-23, 48-49; "First Reunion of Iowa Hornet's Nest Brigade," 10/12-13/1887, series 3, box 4, folder 216, SNMP; Official Records, 1, 10, 1: 277-80. 
In preparation for marking the field, Reed completed two large troop position maps, one for each day of the battle. Combining engineer Atwell Thompson's topography maps with his own knowledge of troop movements, Reed produced very accurate maps of the battle. The diagrams show the action as it unfolded, demonstrating the successive positions of the armies. ${ }^{38}$

More descriptive than the maps was Reed's prose, accurate because he had long been involved in Shiloh's historical scholarship, but overemphasizing the importance of the Hornet's Nest and the Sunken Road. He wrote pamphlets for veterans' organizations, and he would eventually publish the history of his regiment, the 12th Iowa. In 1902, under the auspices of the Shiloh National Military Park Commission and through the Government Printing Office, Reed published a volume titled The Battle of Shiloh and the Organizations Engaged. The book was a slim volume filled with details. After a short history of the commission and a listing of several documents, Reed gave an overview of the campaign and battle. Then, he fulfilled his title by describing the movements of every brigade throughout the battle. Detailed tables of casualties and organization of the armies filled out the volume. Reed's book quickly became the standard treatment of the battle and would remain so for seven decades, influencing many academic works over the years. Even renowned historians such as James McPherson in Battle Cry of Freedom (1988) and Russell Weigley in A Great Civil War (2000) have taken Reed's cue and concentrated their treatment of Shiloh on the Hornet's Nest. ${ }^{39}$

One of Reed's purposes in writing his history of the Battle of Shiloh was to provide veterans with a documented account of the battle, so that they, in turn, could make recommendations and correct any faulty statements. Once Reed published the book, he sent it to a number of veterans and their families free

38. Reed Map, First and Second Days, 1900, series 6, boxes 1 and 2, SNMP.

39. Reed, The Battle of Shiloh and the Organizations Engaged; "First Reunion of Iowa Hornet's Nest Brigade," 10/12-13/1887, series 3, box 4, folder 216, SNMP; "12th Iowa Veteran Volunteer Infantry," ibid., folder 218; James M. McPherson, Battle Cry of Freedom: The Civil War Era (New York, 1988), 410; Russell F. Weigley, A Great Civil War: A Military and Political History, 1861-1865 (Bloomington, IN, 2000), 114. 
of charge. At the same time, he sold it to non-veterans. In return, he received corrections and new eyewitness accounts. By and large, Reed's scholarship withstood this test, but a few corrections prompted the commission to request a second edition, which Reed issued in 1909, with a reprinting in $1913 .^{40}$

AT FIRST, Reed did all of his work while commuting from Evanston to Shiloh. His visits to the battlefield took on the feel of an adventure, with the battlefield's isolation causing delays in travel and its lack of accommodations creating a kind of frontier experience. Cadle had earlier erected tents in the cemetery, but in 1904 the cemetery superintendent had asked that they be removed; they were subsequently placed at the nearby hotel, which by that time was park property. Laborers aligned the tents facing east, but Cadle warned them to wait before aligning Reed's tent so that the picky historian could place his own where he wanted it. To make his quarters feel more like home, Reed nurtured a large rose bush in front of his tent. ${ }^{41}$

A major change occurred in October 1905, when Chief Engineer Thompson resigned. With Thompson's resignation, the commission faced the loss of its resident park director. Someone had to move to the park, and Reed jumped at the chance. He, Ellen, and one of their daughters moved from Illinois into "Review Place," a nice house in the center of the battlefield where Thompson had lived. Reed took his rose bush with him. ${ }^{42}$

With his life becoming ever more focused on Shiloh, Reed directed the park's affairs for the next four years, finishing the initial construction phase. By 1908, the park was almost completed, but tragedy struck in October 1909, when a tornado hit the Pittsburg Landing area. The storm killed seven people and

40. David W. Reed, The Battle of Shiloh and the Organizations Engaged, 2nd ed. (Washington, DC, 1909), 5.

41. J. B. Bellinger to Cornelius Cadle, 1/28/1905, series 1, box 38, folder 629 , SNMP; Cornelius Cadle to Atwell Thompson, 3/22/1905, series 1, box 35, folder 564, SNMP; Atwell Thompson to D. W. Reed, 3/18/1905, series 1, box 38 , folder 628 , SNMP.

42. D. W. Reed to Cornelius Cadle, 6/23/1905, series 1 , box 38 , folder 629 , SNMP; Cornelius Cadle to F. C. Ainsworth, 1/29/1906, series 1, box 31, folder 431, SNMP. 
injured 33, some of whom Reed cared for at his house. He also lodged the commission when they arrived, their tents having been destroyed in the tornado. ${ }^{43}$

In January 1910 another major change occurred when Cadle received notice from the secretary of war that "for some time past the Department has been thoroughly dissatisfied with your method of conducting business. ... It is therefore requested that you immediately forward to me your resignation as a member of said commission." Without even giving notice to Reed, Cadle resigned as commission chairman, effective January 31, 1910. Most likely, Cadle's age and infirmities had left him unable to supervise the park's affairs. Apparently, there had been some correspondence between Reed and the War Department over Cadle's failure to respond to Reed's requests and inquiries. Although Cadle recommended that Reed replace him as commission chairman, the relationship between the two men apparently ended, perhaps indicating that some animosity had developed between them. ${ }^{44}$

Cadle's resignation caused a flurry of activity in the War Department to find his replacement, which ended with Reed's appointment as chairman. Working through the War Department, Reed began to deal with the park's problems systematically. While his appointment kept the park's affairs in the hands of the most knowledgeable individual, it also consolidated jurisdiction. With Thompson's resignation, the original leadership of three had dwindled to Cadle and Reed. Now Reed became the supreme park authority at Shiloh. His residence in the park further consolidated his control. . $^{45}$

43. Cornelius Cadle to Sydney E. Smith, 11/25/1909, series 1, box 4, folder 28, SNMP; Shiloh National Military Park Daily Events, 10/14/1909, SNMP, pp. 274-77.

44. Jacob Dickinson to Cornelius Cadle, 1/15/1910, RG 107, E 82, vol. 44, NARA; Assistant and Chief Clerk to D. W. Reed, 12/6/1909, RG 107, E 82, vol. 44, NARA; Minutes of Commission Meeting, 10/26/1911, hard copy in Shiloh National Military Park Commission Daily Events, SNMP. There seems to have been no post-resignation correspondence between Reed and Cadle.

45. D. W. Reed et al to John B. Randolph, 7/5/1911, series 1, box 36, folder 589, SNMP; Cornelius Cadle to D. W. Reed, 1/31/1910, series 1, box 39, folder 630, SNMP; John T. Wilder Compiled Service Record, NARA. 


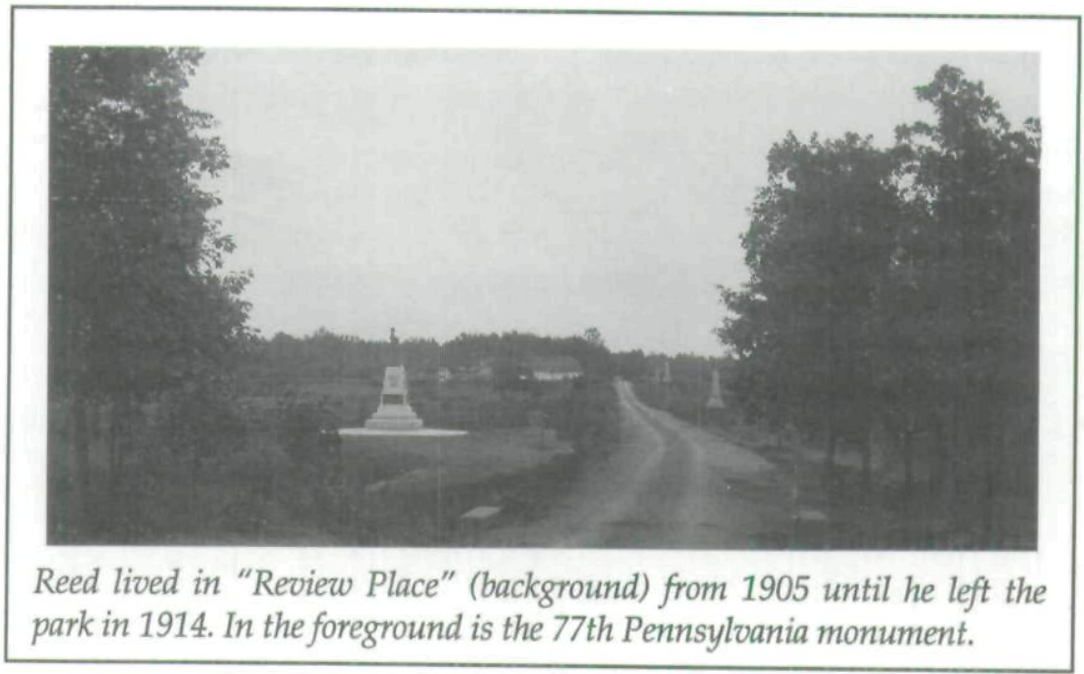

Affairs of the park settled down once again, but this time with Reed in charge. When a new office building was completed in the park, Reed had ample room for storage as well as quarters for the visiting commission. The tornado of 1909 had caused much damage and heartache, but it had nonetheless benefited the park in significant ways. For the first time, the park had an office of its own where it could do business and greet visitors. Most of all, a complete interpretation program, previously limited to the battlefield itself, seemed a real possibility. Reed could now further advance the memory of the battle, and for that matter of the Civil War itself.

Unfortunately, this new opportunity to advance Shiloh's interpretation and improve visitor accommodations did not come to fruition. Reed was an elderly man, and he soon had to bring in additional help to run the park. The national commission system soon also underwent massive changes, again delaying desired alterations at Shiloh. As a result, it was years before all the possibilities the tornado had created could be fully realized.

Yet Reed continued to oversee the building program of the park, including the new headquarters building. A new flagpole went up with great celebration in February 1911. In 1912 workers finished a new pavilion, 40 by 120 feet, just south of the park headquarters. The new facility was furnished with 50 new "settees," drinking fountains of the "bubbling kind," and a "rest 
room for women, toilet rooms and other conveniences." In 1914 Reed marked Grant's headquarters in the cemetery with a pyramid of cannon tubes. Other work went on, too, including fencing and concreting Bloody Pond, which had become "a filthy wallowing place for hogs." Reed was pleased with the progress, writing in the "Daily Events" ledger book that "the Headquarters Office and the new Park Pavilion proved to be [of] great convenience and comfort, this being the first time the Commission has had any suitable place for entertaining any visitors. ${ }^{\prime \prime 6}$

The progress achieved during Reed's solo administration of the park did not end all controversy. Reed continued to defend his interpretation of the battle vehemently. In fact, he became even more combative. He also had a rocky relationship with owners of first the Stantonville Telephone Company and then the Sun Telephone and Telegraph Company, carrying on lengthy arguments over prices, locations of lines, and service. ${ }^{47}$

Reed also battled cemetery officials after they received permission from the secretary of war in 1904 to take some 70 feet of land from the park and move the west wall that distance. When the park commission built its new office building in 1910, it rested only 30 feet from the new west boundary. Surveyors then found an error in the line, which meant that the proposed iron cemetery gates would be within ten feet of the commission's office building. Reed complained and succeeded in getting the entrance gates moved farther south and the west wall moved some five feet to the east. ${ }^{48}$

At times, Reed's combative personality caused him unnecessary trouble. When he caught lawbreakers in the park, he sought to teach them a lesson, even if such action was not strictly within the law. He once fined several white boys for

46. D. W. Reed to Robert Shaw Oliver, $1 / 22 / 1912$, and D. W. Reed to Chicago House Wrecking Co., 1/8/1912, both in RG 79, box 8, NARA-Southeast Region, Atlanta; Shiloh National Military Park Daily Events, 2/22/1911 and April 1912, SNMP, pp. 3, 20; Annual Report of the Secretary of War, 1912, 192; Chief Quartermaster to Chairman Shiloh NMP, 12/22/1913, series 1, box 27, folder 388, SNMP.

47. Terry W. Allen to D. W. Reed, 8/20/1910, series 1, box 40, folder 650, SNMP. 48. D. W. Reed to John C. Scofield, 3/7/1911, series 1, box, 14, folder, 174, SNMP. 
throwing rocks at their black neighbors, and he fined another child ten dollars for killing a squirrel in the park. He allowed the boys to work off their fines for a dollar a day, providing him with help as well as teaching the boys a lesson they would not soon forget. Word of the kangaroo court leaked out, however, and angry parents soon took the matter to the judicial system. By the end of the incident, the United States Attorney General had become involved, and Reed almost faced charges of extortion by threats of violence. On another occasion, Reed locked horns with U.S. marshals. He thought quick judicial proceedings would curb lawlessness in the park, but busy marshals, swamped by other cases, did not act quickly enough for Reed. ${ }^{49}$

The most severe allegations came from park neighbors who complained about the way Reed ran the battlefield. The locals were more disturbed about the arrival of federal authority in their neighborhood than anything else. They complained about Range Rider E. R. Underhill, Assistant Superintendent F. A. Large, and Reed himself. The Justice Department sent the acting Judge Advocate General to the park to investigate, and Large and Underhill were suspended pending a ruling. Reed, however, faced no charges. ${ }^{5}$

Other problems also confronted the aging Reed. The hotel, rebuilt in 1910 after the tornado, burned on the night of December 23, 1913, causing "much inconvenience to visitors and some embarrassment to the authorities." The loss was not as devastating as the loss of the former hotel because the commission now had ample room for offices and quarters. Still, at a time when travel options were limited, accommodations for visitors to such a remote area were necessary. Congress never appropriated the money to rebuild the hotel, however, continuing the emerging pattern of insufficient funding for the park. ${ }^{51}$

Perhaps the most pressing problem Reed faced was finding suitable help for the work at Shiloh. He discovered more and more that he could not handle the job alone; he needed other,

49. George B. Randolph to Attorney General, 5/10/1909, and D. W. Reed to Cornelius Cadle, 5/24/1909, both in RG 92, E 712, box 2, NARA.

50. Shiloh National Military Park Daily Events, September 1913, SNMP, p. 32.

51. Annual Report of the Secretary of War, 1914, 656. 


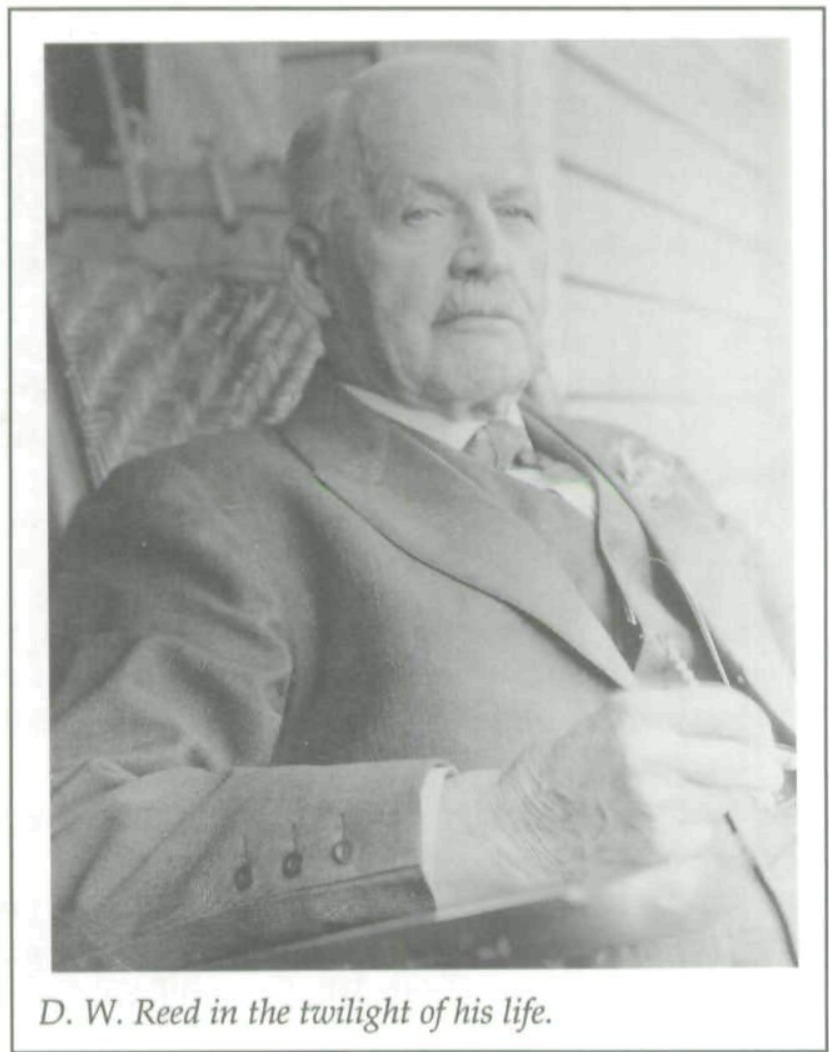

more able-bodied men to carry on day-to-day operations. Reed found that good workers were hard to locate. As a result, he had to hire many individuals before he found competent workers he could trust with the future of the park.

The task of finding a suitable clerk was an example. The park had "never been able to keep a clerk very long, and this has resulted in repeated embarrassment to the work here, in the necessity of installing a new clerk every few months," Reed complained. Indeed, Shiloh had gone through more than its quota of clerks. At times, Reed's daughter Minnie served in temporary capacities. ${ }^{52}$

52. DeLong Rice to A. J. Earl, 4/20/1916, series 1, box 35, folder 533, SNMP; "Invoices" Ledger Book, RG 75, NARA-Southeast Region; Shiloh National Military Park Daily Events, February, April, and August 1912, SNMP, pp. 18, 20, 24; William M. Green Diary, Vertical file, SNMP. 
As a new generation assumed more and more responsibility, Reed and the other commissioners faded away. By 1912, Reed's health was failing. When called to Washington in 1912 to testify concerning appropriations, he sent another commissioner because he was not "just now in very robust health." In May 1913 Reed was thrown from his carriage and "suffered a broken thigh," probably already weak from his battle wound 51 years earlier. The accident ended his mobility, and he was soon forced to hand over his on-site duties to the commission's secretary, DeLong Rice, and return home to Waukon, Iowa, leaving his beloved Shiloh, his rose bushes, and his constant companionhis horse Dan. Reed continued to oversee the park commission from Iowa, however. ${ }^{53}$

REED'S HEALTH steadily deteriorated, and he died on September 22, 1916, just two days past his and Ellen's fiftieth wedding anniversary. Leaving Ellen, Minnie, Gertrude, and Milton (a lieutenant in the U.S. Navy), he was buried in Waukon. Shiloh's most knowledgeable historian was gone. ${ }^{54}$

Recognizing Reed's dedication to and influence on the park, veterans wanted to place a monument to him on the grounds, but government rules preventing glorification of individuals precluded such an act. Undaunted, the National Association of the Survivors of the Battle of Shiloh planned to place a plaque honoring Reed on the office wall, but the War Department denied that request too. Reed's memory could only be preserved in the park itself and in the aging veterans' hearts. ${ }^{55}$

Shiloh veterans were not the only ones to acknowledge their debt of gratitude to David Wilson Reed; hundreds of historians who have written about Shiloh, millions of visitors who have enjoyed the park through the years, and untold numbers of

53. DeLong Rice to D. W. Reed, series 3, box 2, folder 142, SNMP; Commission Minutes, 4/6/1912, found in Shiloh National Military Park Commission Daily Events, April 1912, SNMP, p. 20; Shiloh National Military Park Commission Daily Events, May 1913, SNMP, p. 29; "David Wilson Reed," 353.

54. Annual Report of the Secretary of War, 1917, 1008; Reed, Campaigns and Battles of the Twelfth Regiment, 251.

55. DeLong Rice to Secretary of War, 4/27/1917, and DeLong Rice to Assistant Secretary of War, 6/18/1917, both in RG 92, E 588, box 5, NARA. 
Civil War buffs who have dreamed of places such as the Bloody Pond or the Hornet's Nest are all indebted to him, too. Reed was indeed the "Father of Shiloh National Military Park." He served the longest tenure of any commission-era employee, he was responsible for much of the park's physical monumentation, and he was the chief historian of the battle, never to be surpassed by anyone. Reed's participation in the battle, his dominance in the building of the park, his detailed understanding of the tactical struggle, and his path-breaking interpretation of the battle reserve for him the foremost position in Shiloh park's history. If it had not been for him, Shiloh National Military Park would not be the national treasure it is today. 
Copyright of Annals of Iowa is the property of State of Iowa, by \& through the State Historical Society of Iowa and its content may not be copied or emailed to multiple sites or posted to a listserv without the copyright holder's express written permission. However, users may print, download, or email articles for individual use. 